\title{
O mercado creditício na Bahia colonial (1777-1808)
}

\author{
The credit market in colonial Bahia (1777-1808)
}

\author{
Augusto Fagundes da Silva dos Santos \\ (iD) https://orcid.org/0000-0003-1700-2689 \\ Universidade Estadual de Feira de Santana
}

\begin{abstract}
Resumo: Este artigo analisa o mercado creditício da Bahia entre fins do século XVIII e princípio do século XIX, período marcado pela retomada da economia baiana de exportação, após uma longa conjuntura econômica negativa iniciada desde a invasão holandesa no final do primeiro quartel do século XVII. O objetivo principal deste trabalho é apresentar as principais características do crédito no período, enfatizando a explícita correlação existente entre o mercado creditício e a economia baiana de exportação em que foi possível perceber uma relação positiva para ambos. Além de benéfica, tal relação foi marcada pela dinamicidade, sendo o crédito um elemento relevante para a retomada da referida economia, ao passo que esta foi fundamental para a expansão do setor creditício.
\end{abstract}

Palavras-chave: Mercado créditício. Economia de exportação. Bahia. Período colonial.

Abstract: This article analyzes the credit market in Bahia between the end of the 18th century and the beginning of the 19th century, a period marked by the resumption of the Bahian export economy, after a long negative economic situation, which began since the Dutch invasion at the end of the first quarter of the 17th century. The main objective of this paper is to present the main characteristics of credit in the period, emphasizing the explicit correlation between the credit market and the Bahian export economy, in which it was possible to perceive a positive relationship for both. In addition to being beneficial, this relationship was marked by dynamism, with credit being a relevant element for the resumption of the aforementioned economy, whereas this one was fundamental for the expansion of the credit sector.

Keywords: Credit market. Export economics. Bahia. Colonial period.

\section{Introdução}

Este artigo aborda as características do mercado creditício da Bahia entre os anos de 1777 e 1808, observando como este setor reagiu e, simultaneamente, estimulou a referida economia. $\mathrm{O}$ recorte cronológico inicial da pesquisa se justifica por ser 1777 um ano extremamente relevante para a historiografia econômica, marcado pelo fim do governo de D. José I e de seu ministro, o Marquês de Pombal. Muitas medidas tomadas durante este reinado influenciaram diretamente no funcionamento da atividade creditícia em território colonial. Já o limite cronológico final, ano de 1808 , justifica-se por se tratar do ano da abertura dos portos brasílicos às nações estrangeiras, com o consequente fim do exclusivo metropolitano e a transferência da Corte portuguesa para o Brasil. Estes acontecimentos, em conjunto, se desdobraram em várias modificações relevantes para a economia colonial.

O que pretendemos nesse trabalho é evidenciar a relação entre o setor creditício e a retomada da economia baiana de exportação no final do período colonial, compreendendo de modo mais aprofundado o mercado creditício desse período, principalmente por se tratar de uma conjuntura marcada pelo crescimento e pela diversificação econômica, e pelo declínio financeiro de algumas das principais instituições financeiras da Bahia colonial. (FAGUNDES, 2015, p. 133).

Para atingir esse objetivo, utilizamos os registros manuscritos contidos nos Livros de Notas do $1^{\circ}$ e $2^{\circ}$ ofício de Salvador, atualmente sob a guarda do Arquivo Público da Bahia (APEB) na 
seção Judiciário e produzidos entre os anos de 1777 a 1808. Através do método quantitativo e serial, foram identificadas 5.580 escrituras, sendo que, após exame prévio, foram selecionadas apenas aquelas capazes de fornecer informações específicas sobre o mercado de crédito da Bahia colonial.

As escrituras públicas são documentos de cunho cartorial que compõem os livros de notas dos tabeliães. Na Salvador do final do século XVIII, existiam dois cartórios, onde estava registrada "toda a vida civil local"; tratam-se, portanto, de conjuntos documentais extremamente valiosos para a pesquisa histórica, onde é possível encontrar uma gama variada de assuntos, consistindo numa "radiografia" de uma determinada sociedade.

Depois da seleção, que teve como principal critério a utilização das escrituras que se referissem apenas às atividades creditícias (empréstimos de dinheiro a juros e vendas a prazo), a amostra contou com 1.530 escrituras selecionadas que permitiu obter, no somatório geral, o numerário de 2.329:997\$892 réis. Esta cifra obtida da amostra será utilizada ao longo deste artigo como referência para caracterizar a atividade creditícia na Bahia no período supracitado.

Do valor de $2.329: 997 \$ 892$ réis mencionados, $67 \%$ ou $1.560: 435 \$ 023$ réis foram oriundos de relações que envolveram alguma modalidade de crédito, por exemplo, o empréstimo de dinheiro a juros tomado por Joaquim Teixeira Marques junto ao credor João Teixeira Coelho no valor de 1:200\$000 réis, efetuado em 9 de janeiro de 1807, tendo como garantia hipotecária o bergantim do mutuário (APEB, Livro 156, fólio $11 \mathrm{r}, 11 \mathrm{v}, 11$. R. 9 de janeiro de 1807). Por outro lado, $33 \%$ ou 769:562\$869 réis foram pagos em moeda corrente, como no caso da compra de uma fazenda de terras por $800 \$ 000$ réis, situada na Freguesia de Santo Amaro do Ipitanga, termo da cidade de Salvador, realizada pelo Frei Luiz Pereira, em 21 de julho de 1804, pertencente ao casal Antonio Jozé Pereira Rabello e Clara Maria Nazareth (APEB, Livro 149, fólio 1v. 21 de julho de 1804).

De $67 \%$ do valor total transacionado no período e movimentado a crédito, ou seja, 1.560:435 $\$ 023$ réis, apenas $16,47 \%$ ou $257: 131 \$ 015$ réis se referiram a empréstimos de dinheiro a juros, demonstrando que outras modalidades de crédito que não envolviam o componente monetário, a exemplo das vendas fiadas e pagamentos em espécie, se sobressaíram.

Diante desses números, temos a seguinte disposição gráfica que caracterizou as relações de compra e venda e os empréstimos na Bahia do final do período colonial:

Gráfico 1 - Modalidades de pagamento e empréstimos de dinheiro a juros na Bahia, 1777-1808

(Contos de réis \%)

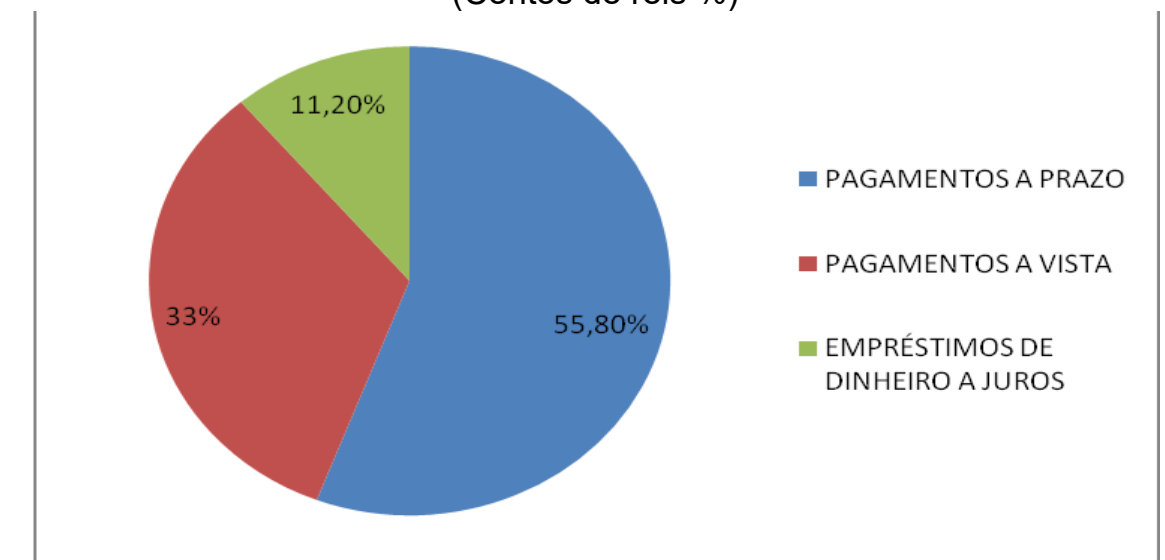

Fonte: Elaboração do autor baseado em dados coletados no APEB. Seção: Judiciário; Livros de Notas do $1^{\circ}$ e $2^{\circ}$ ofício de Salvador, anos de 1777 a 1808.

A partir do Gráfico $n^{\circ} 1$, é possível perceber que a maior parte do valor transacionado na Bahia entre 1777 e 1808, foi de vendas a prazo, representando mais da metade das cifras registradas nas escrituras do período. Foram exatos $55,8 \%$ do montante total que se referiram a pagamentos a crédito. Em segundo lugar, vieram os pagamentos à vista, perfazendo $33 \%$ do universo financeiro, e em terceiro e último lugar ficaram os empréstimos de dinheiro a juros, com 


\section{$11,2 \%$ do total.}

Quando o critério dos dados foi modificado para observar a economia da Bahia no final do período colonial, saindo das cifras em direção a quantidade de escrituras, a sequência se manteve igual. Na primeira posição, as escrituras de vendas a prazo, na segunda colocação, os pagamentos à vista e, na última posição, os empréstimos de dinheiro a juros. No entanto, o peso de cada um em relação ao universo quantitativo da documentação cartorária se modificou, como veremos no Gráfico $n^{\circ} 2$ :

Gráfico 2 - Modalidades de pagamento e empréstimos de dinheiro a juros na Bahia, 1777-1808 (Contos de réis/Quantidade de escrituras \%)

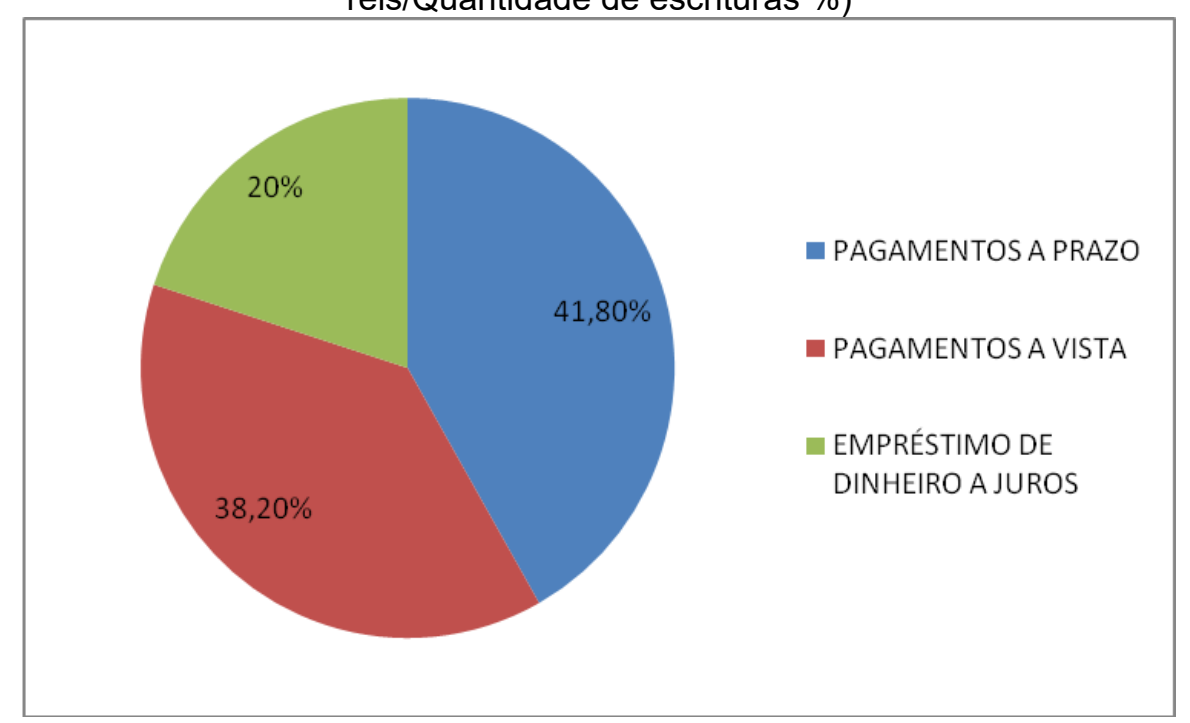

Fonte: Elaboração do autor baseado em dados coletados no APEB. Seção: Judiciário; Livros de Notas do $1^{\circ}$ e $2^{\circ}$ ofício de Salvador, anos de 1777 a 1808.

Comparando-se o Gráfico $n^{\circ} 1$ com o Gráfico $n^{\circ} 2$, para relacionar o peso econômico de cada tipo de escritura e as suas quantidades, observa-se que os pagamentos a prazo tiveram participação menor. Saíram de 55,8\%, quando o critério foi o peso econômico, para $41,8 \%$, quando o critério foi o número de escrituras, representando uma queda de $25 \%$. Esses dados permitem inferir que o valor médio das vendas a prazo foi mais significativo do que o das outras modalidades de escritura. Por outro lado, quando o critério foi a quantidade de escrituras, tanto o número de vendas à vista, quanto o número de empréstimos de dinheiro a juros, cresceram, significando que ambos tiveram valor médio mais baixo.

Quando os bens transacionados eram de valores menores, os moradores da Capitania, seja por não dispor de crédito ou por não necessitar dele, optaram por pagar à vista. Em $38,2 \%$ dos casos, a opção foi por esta modalidade de pagamento.

As cifras movimentadas com os pagamentos em moeda não tiveram tanta disparidade em relação à sua quantidade, aumentando apenas $15 \%$, saindo de $33 \%$ em termos de participação monetária, para $38,2 \%$ quando relativo a sua quantidade.

A disparidade maior, portanto, ficou por conta dos empréstimos, que representando apenas $11,2 \%$ do universo de dinheiro identificado no período, cresceu exponencialmente, em torno de $78,6 \%$, chegando a $20 \%$ em relação ao volume quantitativo de escrituras. O valor médio dos empréstimos de dinheiro a juros foi, portanto, o menor entre os três tipos de transações, demonstrando que nessa economia o dinheiro era uma mercadoria muito valorizada e que a sociedade baiana colonial, de um modo geral, possuía receios em colocar seu capital-dinheiro a risco, privilegiando a concessão de crédito em espécie, ao invés de aventurar sua moeda entesourada. utilizadas.

A seguir, o Gráfico $n^{\circ} 3$ traz o valor médio movimentado nos três principais tipos de escritura 
Gráfico 3 - Valor médio transacionado por tipo de escritura na Bahia, 1777-1808 (contos de réis)

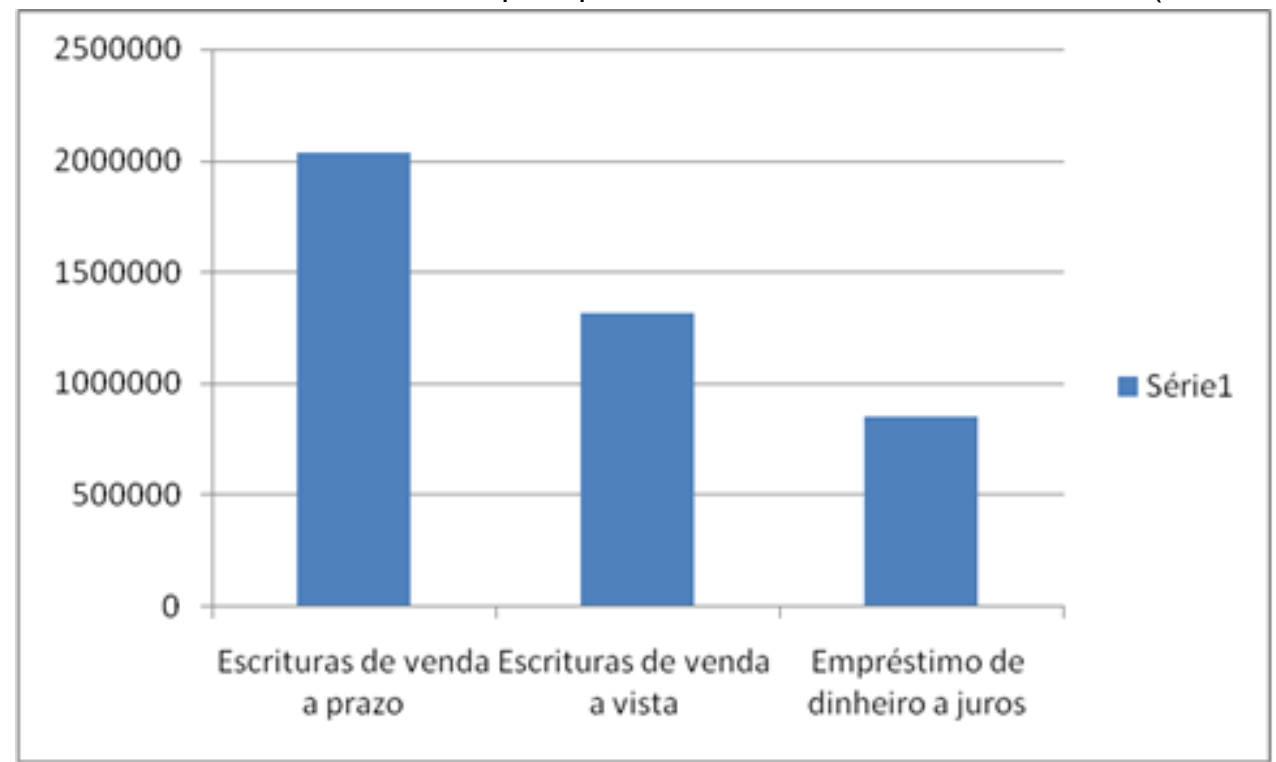

Fonte: Elaboração do autor baseado em dados coletados no APEB. Seção: Judiciário; Livros de Notas do $1^{\circ}$ e $2^{\circ}$ ofício de Salvador, anos de 1777 a 1808.

O Gráfico $n^{\circ} 3$ confirma a constatação de que o valor médio das escrituras de vendas a prazo foi superior em relação às escrituras de vendas à vista e, principalmente, em relação ao valor médio dos empréstimos de dinheiro a juros.

Segundo a documentação analisada, as escrituras de vendas fiadas tiveram um valor médio de 2:032\$777 réis, valor $35,3 \%$ superior ao das escrituras de vendas à vista, que tiveram valor médio de 1:315\$492 réis. Já o valor médio dos empréstimos de dinheiro a juros não chegou a um conto de réis, montando em exatos $850 \$ 679$ réis, $58,1 \%$ a menos do que as escrituras de venda a prazo e $35,3 \%$ menos do que as vendas à vista.

Uma vez exposta a documentação e os valores e as quantidades nelas registrados, serão apresentadas as características do crédito na Bahia e a sua relação com a economia de exportação no final do período colonial.

\section{O movimento creditício na Bahia}

Denomina-se crédito todas as vendas a prazo somadas aos empréstimos de dinheiro a juros. Analisaremos a seguir, os movimentos do crédito na Bahia no período de 1777 a 1808. 
Gráfico 4 - Volume de concessão de crédito, Bahia (1777-1808)

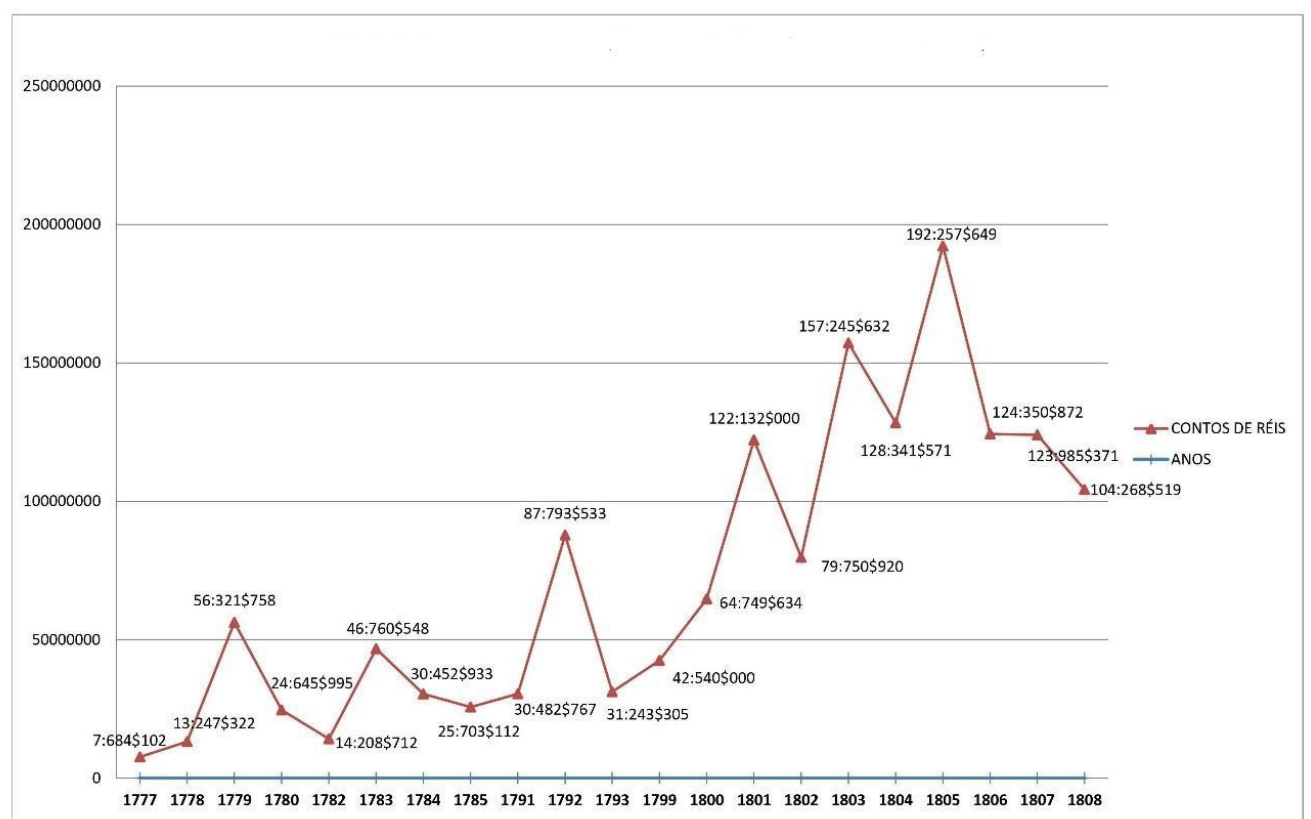

Fonte: Elaboração do autor baseado em dados coletados no APEB. Seção: Judiciário; Livros de Notas do $1^{\circ}$ e $2^{\circ}$ ofício de Salvador, anos de 1777 a 1808.

Apesar das oscilações, pode-se perceber que a curva geral do movimento creditício na Bahia, entre 1777 e 1808, foi ascendente até 1805.

O primeiro ano pesquisado foi o de menor concessão de crédito, ano de 1777 . Os prestamistas não poderiam prever que o preço do açúcar, a partir daquele momento, iria aumentar significativamente. A Guerra de Independência da colônia britânica na América do Norte e a consequente desorganização das atividades comerciais entre a Inglaterra e as Antilhas elevaram o preço do açúcar no mercado mundial (BARICKMAN, 2003, p. 71), resultando no aquecimento do mercado creditício baiano no final da década de 1770.

De 1777 para o ano seguinte, a concessão de crédito quase duplicou, saindo de 7:684\$102 réis para $13: 247 \$ 322$ réis. No ano de 1779 , o fornecimento de crédito ampliou-se ainda mais, subindo mais de $300 \%$ em relação a 1778 , atingindo a marca de 56:321\$758 réis, demonstrando como os produtores baianos reagiram rápido e positivamente à conjuntura favorável, puxada pelo açúcar, de elevação dos preços no mercado externo. No ano seguinte, houve uma queda considerável na atividade creditícia, mas, mesmo assim, a cifra atingiu quase o dobro de dois anos antes, e mais do que o triplo do ano inicial dessa pesquisa. Fechou-se o ano de 1780 com o volume de crédito fornecido na Bahia na faixa dos 24:000\$000 réis.

Por causa do estado de degradação dos Livros de Notas, não foi possível obter nas fontes documentais disponíveis dados sobre a atividade creditícia para o ano de 1781, entretanto, assim como o ano de 1782, há fortes razões para conjecturar que foi um ano de declínio, pois existiu nesse período um arrefecimento nos preços do açúcar nas principais praças comerciais da Europa. (BARICKMAN, 2003, p. 71) Segundo nossa amostragem, foram concedidos, em 1782, 14:208\$712 réis em créditos. Apesar de ser um valor considerado baixo, esse montante foi superior aos valores concedidos a crédito nos dois primeiros anos da série aqui analisada.

Em 1783, o mercado de crédito baiano voltou a aquecer, crescendo mais de $200 \%$ em relação ao ano anterior, atingindo o montante de 46:760\$548 réis. Esse crescimento, provavelmente, foi impulsionado pelo setor fumageiro, pois no início dos anos de 1780, talvez o fumo tenha sido mais importante do que o açúcar para o mercado de crédito baiano. Segundo Barickman, na década de 1780, "....as exportações de fumo haviam quase duplicado, chegando a uma média anual de 615 mil arrobas. Picos posteriores, na década de $1790 \ldots$ confirmaram a recuperação do fumo." (BARICKMAN, 2003, p. 65). 
Os anos de 1784 e 1785 foram marcados por duas quedas consecutivas no volume de crédito concedido, com valores respectivos de $30: 452 \$ 933$ réis e $25: 703 \$ 112$ réis. Pelos motivos já apresentados não foi possível dispor de dados para os anos de 1786 a 1790, entretanto, arrisca-se afirmar que as oscilações continuaram, mas os picos não devem ter ultrapassado a cifra mais alta até aqui apresentada, atingida no ano de 1779, no valor superior a 56:000\$000 réis.

O início da década de 1790 foi marcado pela expansão do mercado creditício. Em 1791, no entanto, o crescimento ainda foi tímido, de apenas 5:000\$000 réis em relação a 1785 , quando o volume creditício girou em torno dos 25:000\$000 réis. $O$ ano de 1792, por seu turno, atingiu um novo recorde dentro das balizas temporais dessa amostragem, no valor de 87:793\$533 réis. Nesse momento, é impossível desprezar as influências exercidas pelos resquícios da guerra na América do Norte e, principalmente, o aumento significativo da demanda externa por algodão, causado pelo advento da Revolução Industrial inglesa. Os negociantes baianos estavam atentos a essa nova conjuntura e fomentaram a cotonicultura na região de Inhambupe e Alagoinhas. De fato, o porto de Salvador passou a exportar cada vez mais algodão advindo dessa região, a partir da década de 1790. Consoante ao que afirma Barickman:

[...] as exportações de algodão a partir de Salvador tiveram um aumento extraordinário no final do século XVIII e início do século XIX. Passaram de menos de cem arrobas por ano na década de 1770 para uma média anual de quase quarenta mil arrobas na segunda metade da década de 1790. (BARICKMAN, 2003, p. 59).

Em 1793, a atividade creditícia na Bahia registrada nas escrituras voltou a cair, atingindo a cifra de 31:243\$305 réis. Para os anos de 1794 a 1798 não se dispõe de dados, mas acredita-se que houve uma tendência de alta no volume de crédito fornecido, haja visto que, açúcar, fumo e algodão, em conjunto, estavam em expansão produtiva na Bahia e seus preços com tendência de alta no mercado externo.

Os anos de 1798 e de 1799 foram marcados por um clima de instabilidade política em Salvador em decorrência da Revolta dos Búzios, no entanto, antes é necessário dizer que nos primeiros decênios do século XVIII, a economia baiana, a exemplo dos últimos anos do século XVII, ainda estava estagnada, resultado do crescimento da concorrência estrangeira na produção do açúcar. A partir de meados do século XVIII, uma série de acontecimentos permitiu a retomada da produção e dos preços dos principais produtos baianos no mercado externo, tais como: a Revolução Industrial e a guerra de Independência na América Inglesa que provocaram aumento da demanda pelo algodão e a Revolução escrava na colônia francesa de São Domingos que desorganizou a maior região produtora de açúcar e de café mundial à época, contribuindo decisivamente para a retomada da produção baiana no final do período colonial. A estes fatores exógenos, podemos incluir a preocupação do Estado português, a partir do período pombalino, em ampliar e diversificar a produtividade agrícola como elemento fundamental na implementação das reformas econômicas. (RAMINELLI, 2008, p. 70-83)

Esta retomada da economia de exportação contribuiu para a inflação nos preços dos produtos de primeira necessidade. A tendência inflacionária no custo da alimentação da população deve ter sido um ingrediente a mais para a Sedição. A rápida e violenta decisão da Coroa, que em menos de um ano, em novembro de 1799, decidiu pelo enforcamento e o esquartejamento em praça pública de alguns revoltados, indica que era um momento de extremo cuidado pela manutenção do exclusivo metropolitano. (TAVARES, 2001; BORGES, 2015).

Os três anos seguintes, 1799, 1800 e 1801, foram de alargamento do setor creditício na Bahia e os valores concedidos foram, respectivamente, de 42:540\$000, 64:749\$634 e 122:132\$000 réis. O ano de 1801 marcou, pela primeira vez nessa amostragem, que o volume de crédito fornecido a juros ultrapassou a barreira dos 100:000\$000 réis. Apenas no ano seguinte, em 1802, ocorreu uma queda, cuja cifra registrada ficou abaixo dos 100:000\$000 réis. Já em todos os anos seguintes, até o fim da amostragem, em 1808, a despeito das oscilações, o volume de crédito 
fornecido na Bahia jamais foi inferior à barreira dos 100:000\$000 réis.

Em 1803, o volume de crédito concedido bateu o novo recorde da série, atingindo 157:245\$632 réis. Em 1804, houve uma queda suave, com a cifra importando no segundo maior montante emprestado por ano desde 1777 , no valor de 128:257\$649 réis. O maior pico de crédito a juros na Bahia, no final do período colonial, estava por vir no ano seguinte. As escrituras demonstram que o volume de crédito fornecido a juros em 1805 foi maior do que em qualquer outro ano dessa amostragem: seu valor chegou próximo dos 200:000\$000 réis.

O bom momento do setor creditício esteve diretamente relacionado ao aumento da produção e ao incremento dos preços dos principais produtos baianos de exportação no mercado externo. Os últimos anos do século XVIII e primeiros anos do século XIX foram extremamente positivos para a economia baiana de exportação, encorajando produtores a investir na ampliação da produção e estimulando os credores a concederem mais créditos a juros.

No ano de 1805, exercício de maior atividade creditícia, a Bahia exportou entre açúcar branco e mascavado 908.764 mil arrobas. (ARRUDA, 1980, p.361-376). No ano seguinte, arrefeceu o financiamento e desacelerou, mesmo que em intensidade menor, a produção. Em 1806, as escrituras de Salvador registraram 124:350 $\$ 872$ réis de créditos concedidos, enquanto a exportação do açúcar baiano foi de 893.144 mil arrobas. (ARRUDA, 1980, p.361-376).

O mercado de crédito e a economia de exportação da Bahia se mantiveram aquecidos e estáveis até o exercício de 1807. Nesse ano, o volume de crédito concedido praticamente se manteve igual, 123:985\$371 réis, e a exportação de açúcar no porto de Salvador teve um leve crescimento de cerca de 6,6\%, saltando de 893.144 arrobas, em 1806, para 953.377 arrobas, em 1807. (ARRUDA, 1980, p. 361, 376).

O período positivo da economia de exportação sofreu uma queda brusca com a invasão das tropas napoleônicas em Portugal em 1807, dificultando o translado de mercadorias entre as praças da Bahia e de Lisboa. Como consequência, percebe-se o declínio dos principais produtos de exportação.

Utilizando apenas o açúcar como referência, tem-se que as exportações desse produto da Bahia para Portugal, após a invasão francesa, despencou de 953.377 arrobas, em 1807, para modestas 101.947 arrobas, em 1808. Esse é o número mais baixo das exportações de açúcar desde 1796. (ARRUDA, 1980, p. 361, 376).

Com o declínio das exportações, caiu também a demanda/oferta de crédito, não na mesma proporção das exportações de açúcar, mas declinou de 123:985\$371 réis, em 1807, para 104:268 \$519 réis, em 1808, queda de 15,3\%. O ambiente de insegurança em Portugal arrefeceu 0 ímpeto tanto de emprestadores quanto de tomadores, reduzindo a atividade econômica como um todo na Bahia no ano de 1808.

Os desdobramentos da invasão das tropas francesas em Portugal foram marcados pela transferência da Corte portuguesa para o Brasil, o que, aliado à decisão de D. João em abrir os portos às nações estrangeiras em 1808, permitiu a recuperação das exportações no ano de 1809, e uma nova curva de crescimento no fornecimento de crédito a juros se estabeleceu, no entanto, essa discussão foge ao escopo desta pesquisa.

Para demonstrar o quanto a atividade creditícia foi relevante para a retomada da economia de exportação, elaboramos o Gráfico 5. São cruzados os dados sobre o crédito na Bahia, com os dados da economia baiana de exportação de José Jobson de Arruda (1980). 
Gráfico 5 - Relação - Volume de crédito concedido / Economia de exportação (\%)

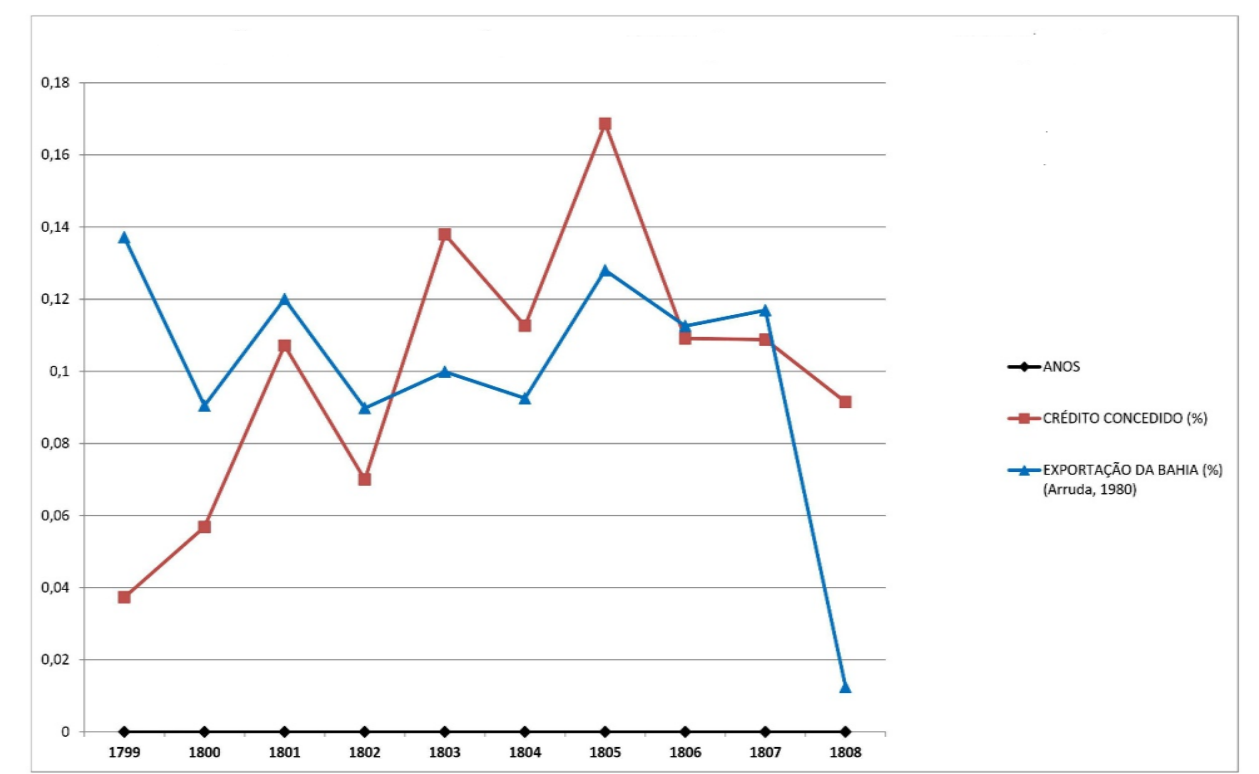

Fonte: Elaboração do autor baseado em dados coletados no APEB; Seção: Judiciário; Livros de Notas do $1^{\circ}$ e $2^{\circ}$ ofício de Salvador, anos de 1777 a 1808 e nos dados disponíveis em ARRUDA, 1980, p. 141-142.

O que se verifica, a partir do Gráfico 5, é que havia uma tendência da atividade creditícia em acompanhar as flutuações da economia de exportação. Excetuando o ano de 1799, em que a economia baiana de exportação caiu $34 \%$, enquanto a atividade creditícia cresceu $36,1 \%$, o que é um fato isolado e que pode ser justificado pela aposta dos produtores e dos investidores na manutenção dos preços elevados dos principais produtos baianos de exportação, nos demais anos houve uma relação diretamente proporcional.

No ano de 1800 para o ano de 1801, a economia baiana de exportação saltou de 2.640:773\$886 réis para 3.503:054\$984, aumento de $32,6 \%$. Nesse mesmo período, o mercado de crédito também cresceu, mas em ritmo mais acelerado, saindo de 64:749\$634 réis para $122: 132 \$ 000$ réis, crescimento de $88,6 \%$.

Do ano de 1801 para o exercício seguinte, a atividade creditícia declinou, dos mencionados 122:132\$000 réis para $79: 750 \$ 920$ réis, queda de $34,7 \%$. Já os saldos das exportações, também caíram, de 3.503:054\$984 réis, para 2.619:791\$581 réis, declínio de $25,2 \%$.

De 1802 para 1803, houve nova fase de crescimento, tanto no volume de crédito concedido, saltando de $79: 750 \$ 920$ réis para 157:245\$632 réis, crescimento de $97,1 \%$, quanto da economia de exportação, saltando de 2.619:791\$581 réis para 2.914:221\$114 réis, crescimento de $11,2 \%$.

De 1803 para 1804, ambas voltaram a cair. Enquanto a atividade creditícia declinou 18,5\%, saindo de 157:245\$632 réis para 128:341\$571 réis, a economia de exportação decresceu 7,9\%, de 2.914:221 \$114 réis para 2.699:631\$956 réis.

$\mathrm{Na}$ comparação do ano de 1804 com o ano de 1805, percebe-se que ambas crescem exponencialmente. Enquanto a atividade creditícia atingiu a sua maior cifra, 192:257\$649 réis, crescendo $49,8 \%$ em relação ao ano anterior, a pauta de exportações também registrou a vultosa soma de 3.735:851\$599 réis, segundo maior valor desta amostragem, representando um crescimento de $38,4 \%$ em relação ao ano anterior.

A comparação entre a atividade creditícia na Bahia e as cifras auferidas pela sua economia de exportação demonstram que ambas sofreram queda em 1806 na comparação com o ano anterior. Enquanto o mercado de crédito baiano retraiu-se em $35,3 \%$, saindo da faixa dos 190:000 $\$ 000$ réis para a faixa dos 120:000\$000 réis, a economia de exportação encolheu 13,7\%, caindo de 3.735:851 $\$ 599$ réis para 3.284:684\$868 réis.

O ano de 1807 foi marcado pela estabilidade, enquanto o crédito declinou ínfimos $365 \$ 501$ réis ou $0,29 \%$ e as receitas da economia baiana de exportação cresceram o modesto número de 
3,9\%, menor taxa de crescimento registrada entre 1799 e 1808.

E, por fim, na comparação entre os exercícios de 1807 e de 1808, o movimento entre a arrecadação da economia de exportação e o mercado de crédito baiano também foram semelhantes: ambos os setores tiveram declínio acentuado nesse período por conta da invasão das tropas francesas em Portugal. O mercado de crédito recuou 15,9\%, saindo de 123:985\$371 réis para 104:268 $\$ 519$ réis, enquanto a economia baiana de exportação sentiu ainda mais o golpe, saindo de $3.412: 073 \$ 030$ réis, em 1807 , para $363: 158 \$ 270$ réis, em 1808 , retraindo exorbitantes $89,4 \%$.

A despeito da variação das taxas de crescimento e de declínio, o que se percebe é que o mercado de crédito tendeu a acompanhar os movimentos da economia baiana de exportação, demonstrando como o crédito foi peça-chave para a retomada da economia de exportação no final do período colonial. O crédito estimulava o crescimento da produção e do comércio, ao passo que, quando esses iam bem, retroalimentavam o próprio setor creditício, numa estreita relação. Como os produtos de exportação eram viáveis economicamente apenas quando produzidos em larga escala, caracterizando esse setor como os maiores demandatários do crédito, quando o setor exportador não atravessava uma boa fase, refletia negativamente no setor creditício. Esta é a prova empírica da importância do crédito para a retomada da economia baiana de exportação no final do período colonial.

A seguir discutiremos um tipo específico de crédito na Bahia do final do período colonial, os empréstimos de dinheiro a juros.

\section{Empréstimos de dinheiro a juros}

Embora os empréstimos de dinheiro a juros tenham representado a minoria quantitativa na amostragem, $11,2 \%$ do valor transacionado e $20 \%$ do total das escrituras, examinar com mais acuidade esta modalidade de crédito é de suma importância por se tratar de uma economia que a historiografia tratou como escassa monetariamente.

A partir dos dados extraídos dos Livros de Notas, tem-se o seguinte quadro:

Quadro $1-$ Empréstimo de dinheiro a juros, Bahia $(1777-1808)$
\begin{tabular}{|r|r|r|}
\hline Ano & Valor emprestado (Contos de réis) & $\%$ \\
\hline 1777 & $4: 500 \$ 300$ & $1,75 \%$ \\
\hline 1778 & $1: 108 \$ 520$ & $0,43 \%$ \\
\hline 1779 & $2: 016 \$ 000$ & $0,78 \%$ \\
\hline 1780 & $4: 913 \$ 348$ & $1,91 \%$ \\
\hline 1782 & $6: 042 \$ 205$ & $2,35 \%$ \\
\hline 1783 & $6: 638 \$ 066$ & $2,58 \%$ \\
\hline 1784 & $5: 499 \$ 000$ & $2,14 \%$ \\
\hline 1785 & $11: 591 \$ 514$ & $4,51 \%$ \\
\hline 1791 & $5: 899 \$ 808$ & $2,29 \%$ \\
\hline 1792 & $19: 765 \$ 820$ & $7,69 \%$ \\
\hline 1793 & $6: 550 \$ 800$ & $2,55 \%$ \\
\hline 1799 & $400 \$ 000$ & $0,16 \%$ \\
\hline 1800 & $36: 851 \$ 034$ & $14,33 \%$ \\
\hline
\end{tabular}




\begin{tabular}{|r|r|c|}
\hline Ano & Valor emprestado (Contos de réis) & $\%$ \\
\hline $\mathbf{1 8 0 1}$ & $15: 133 \$ 810$ & $5,89 \%$ \\
\hline $\mathbf{1 8 0 2}$ & $6: 815 \$ 586$ & $2,65 \%$ \\
\hline $\mathbf{1 8 0 3}$ & $14: 850 \$ 973$ & $5,78 \%$ \\
\hline $\mathbf{1 8 0 4}$ & $21: 287 \$ 971$ & $8,28 \%$ \\
\hline $\mathbf{1 8 0 5}$ & $28: 279 \$ 984$ & $11,00 \%$ \\
\hline $\mathbf{1 8 0 6}$ & $37: 572 \$ 727$ & $14,61 \%$ \\
\hline $\mathbf{1 8 0 7}$ & $14: 540 \$ 090$ & $5,65 \%$ \\
\hline $\mathbf{1 8 0 8}$ & $6: 873 \$ 459$ & $2,67 \%$ \\
\hline TOTAL & $\mathbf{2 5 7 : 1 3 1 \$ 0 1 5}$ & $\mathbf{1 0 0} \%$ \\
\hline
\end{tabular}

Fonte: Elaboração do autor baseado em dados coletados no APEB. Seção: Judiciário; Livros de Notas do $1^{\circ}$ e $2^{\circ}$ ofício de Salvador, anos de 1777 a 1808.

Os dados do Quadro 1 demonstram que o volume de concessão de empréstimos de dinheiro a juros iniciou a série de forma tímida, nos anos de 1777, 1778 e 1779, com patamares na faixa dos quatro contos, dois contos e um conto de réis, respectivamente. Em 1780, no entanto, o setor prestamista voltou ao patamar dos 4:000\$000 réis. Em 1782 e 1783, cresceu para a faixa dos 6:000\$000 réis.

No ano de 1784, verifica-se uma pequena retração, caindo para a faixa dos 5:000 $\$ 000$ réis, entretanto, no ano seguinte, atingiu o nível mais alto da série até então, rompendo a barreira dos 11:000\$000 réis. Esse crescimento do setor financista da Bahia na primeira metade da década de 1780 pode ser atribuído à expansão do setor fumageiro.

Como é sabido, não se dispõe de dados para os anos de 1786 a 1790, mas acredita-se que as oscilações se mantiveram e que os valores emprestados a juros não devem ter ultrapassado o valor mais alto até aqui registrado, de 11:591\$514 réis, no ano de 1785.

Em 1791, os empréstimos registrados nos cartórios de Salvador ficaram em cerca de 5:000 $\$ 000$ réis. Em 1792, os valores emprestados cresceram exponencialmente, quebrando em muito o recorde dos 11:000\$000 réis, alcançado no exercício de 1785, atingindo quase 20:000\$000 réis. Ao que tudo indica, esse aumento súbito na demanda por dinheiro tem relação com a Revolução dos escravizados em São Domingos, iniciada no ano anterior. Esse episódio deve ter aumentado o otimismo dos senhores de engenho baianos, desencadeando maior busca por empréstimos para o incremento da produção. (FAGUNDES, 2015).

Em 1793, ocorreu um novo declínio, para a faixa dos 6:000\$000 réis. Não estão disponíveis os dados dos exercícios de 1794 a 1798, mas conjectura-se haver uma tendência de expansão dos empréstimos de dinheiro a juros, pois a situação no período era de plena retomada da economia baiana de exportação. Tanto a produção dos principais produtos de exportação estava sendo ampliada, quanto os seus preços estavam elevados no comércio exterior.

$\mathrm{O}$ ano de 1799 foi surpreendentemente baixo no que tange aos empréstimos de dinheiro a juros. Foram registrados apenas $400 \$ 000$ réis fornecidos em moeda nesse exercício. É relevante afirmar que as atividades prestamistas oscilaram bastante de um exercício para o outro e que, além disto, tiveram uma trajetória própria, específica, desvinculadas do crédito como um todo. Isso se deve ao fato de que, enquanto nas vendas fiadas se vendia uma mercadoria qualquer, nesse caso a mercadoria vendida era o próprio dinheiro.

O dinheiro e suas formas de circulação e materialidade nessa sociedade era algo muito valorizado, não uma valorização superficial, associada apenas a um fator principal, como no caso dos historiadores que atribuem peso excessivo a sua escassez no Brasil colônia. (FLORY, 1978; 
SCHWARTZ, 1988; SAMPAIO, 2003). Seu alto valor na sociedade examinada se deveu a um emaranhado de fatores, de ordem não apenas econômica, mas também social e cultural. (MASCARENHAS, 1998, p. 218).

O numerário na Bahia foi, por vezes, escasso, o que certamente o valorizou economicamente, mas se faz necessário afirmar que o dinheiro no período colonial tinha valor intrínseco, ou seja, além de dinheiro era também metal precioso e como tal se constituiu dentro das teorias mercantilistas do período moderno, ou seja, como um artigo que se manifestou, na prática, como algo que social e culturalmente deveria ser cuidado, guardado e entesourado. Seu alto valor, não apenas do ponto de vista econômico como do ponto de vista social e cultural, reverberou, na prática, não necessariamente na sua escassez, mas na sua indisponibilidade. Ou seja, o dinheiro existia, mas pelos motivos expostos, nem sempre estava disponível.

Optava-se, na sociedade baiana, por ofertar créditos em espécie, o dinheiro, ou seja, as moedas se caracterizaram muitas vezes enquanto reserva de valor, utilizado em casos excepcionais, ou quando, por exemplo, os lucros compensavam os riscos.

Portanto, quando se tratou de crédito, o último recurso utilizado pelos agentes, na Bahia do final do período colonial, era a moeda. Isso explica o valor dos empréstimos terem sido infinitamente menores do que a atividade creditícia como um todo.

No último ano do século XVIII, o setor cresceu vertiginosamente, somando mais de 36:000\$000 réis. A atividade açucareira certamente alavancou a demanda por empréstimos e, não coincidentemente, foi nesse ano que a Coroa encerrou a arrematação dos contratos do dízimo do açúcar, pois percebeu que era mais lucrativo arrecadar diretamente. (MATTOSO, 1972, p. 52).

O século XIX iniciou com duas quedas consecutivas na atividade prestamista, cerca de 15:000\$000 réis, em 1801, e de 6:000\$000 réis, em 1802. O ano de 1803 foi marcado pelo início da recuperação do setor creditício, que cresceu ininterruptamente por quatro anos, alcançando seu ápice em 1806, quando o volume de empréstimos atingiu a marca de 37:572\$727 réis. No ano de 1807, o setor prestamista voltou a cair, registrando o valor de 14:540\$090 réis. O ano de 1808 foi caracterizado pela retração considerável do mercado de crédito, resultado da invasão francesa em Portugal. Foram apenas 6:873\$459 réis o volume de dinheiro emprestado a juros no último ano dessa série.

A Tabela 1 revelou que o movimento dos empréstimos a juros não foi sincrônico com o movimento creditício como um todo (empréstimos + vendas a prazo). Assim, tem-se, como exemplo, que os anos de maior volume na concessão de empréstimos a juros foram respectivamente 1806, 1800 e 1805, enquanto os três maiores exercícios no fornecimento de crédito, de um modo geral, ocorreram respectivamente em 1805, 1803 e 1804.

Quando se observa os menores montantes, há semelhante descompasso, sendo os três anos de menor volume de dinheiro a juros os anos de 1799, 1778 e 1779, respectivamente. Quando se compara com o mercado creditício como um todo, no mesmo período, verifica-se que os três piores anos em termos de valores, foram respectivamente 1777, 1778 e 1782. Portanto, das duas comparações com doze anos distintos, apenas em uma delas houve coincidência, tendo o ano de 1778 como o segundo menor valor de crédito concedido e de empréstimos de dinheiro a juros. Os demais anos não coincidiram, demonstrando que a atividade prestamista possuía características próprias.

As diferenças entre ambos não param por aí. Outro elemento relevante se refere ao valor envolvido em cada transação. Encontram-se empréstimos de dinheiro desde os $40 \$ 000$ réis, como foi o caso do sapateiro Garcia Pereira que, em 28 de agosto de 1805, tomou a juros essa quantia junto a Manoel Oliveira Barroso, para pagar no prazo de oito meses com os juros da lei ${ }^{1}$, até os 8:057\$315 réis. O mesmo se deu no caso do "Vigário Francisco Ferreira Pacheco que, em 14 de julho de 1807, firmou escritura de débito, obrigação e hipoteca à sua credora Ana Quitéria do

\footnotetext{
${ }^{1}$ Arquivo Público do Estado da Bahia; Seção: Judiciário; Livro de notas nº 154, fls. 12e12 v.
} 
Nascimento Castro se obrigando o referido, a pagar o valor mais os juros, sob pena de perder seus engenhos de açúcar com todas as benfeitorias e escravos,"· Já a média geral dos empréstimos, no entanto, foi de $840 \$ 911$ réis, enquanto a média anual variou entre $200 \$ 000$ réis, em 1799 , até $1: 878 \$ 636$ réis, em $1806 .^{2}$

\section{Considerações finais}

Ao cabo, conclui-se que o mercado creditício baiano, no final do período colonial, esteve fortemente aquecido. Como constatou-se, quase $70 \%$ dos valores transacionados nos cartórios de Salvador, entre os anos de 1777 a 1808, envolveram alguma modalidade de crédito. $\mathrm{O}$ formato predominante de acesso ao crédito, no entanto, foi o de vendas a prazo: quase $56 \%$ do montante total computado se referia a pagamentos a crédito. Os empréstimos de dinheiro a juros perfizeram apenas cerca de $11 \%$ do total transacionado na Bahia. Já as vendas à vista representaram mais de $30 \%$, sugerindo que a economia baiana no período não sofria com escassez monetária.

Além do peso de cada modalidade de pagamento no conjunto total da documentação, os dados permitiram calcular o valor médio de cada tipologia escritural.Também nesse caso a liderança foi ocupada pelas escrituras de vendas fiadas, que tiveram um valor médio superior aos dois contos de réis, valor $35,3 \%$ superior ao das escrituras de vendas à vista, cujo valor médio foi de 1:315\$492 réis. O valor médio dos empréstimos de dinheiro a juros foi ainda menor, montando em $850 \$ 679$ réis, $58,1 \%$ a menos do que as escrituras de vendas a prazo, indicando que, nessa economia, o dinheiro era uma mercadoria muito valorizada e que, ao que tudo indica, a sociedade baiana, de um modo geral, possuía ressalvas quanto ao investimento de dinheiro a juros, optando, enquanto modalidade principal de crédito, pelo fornecimento de bens em espécie para pagamento a prazo.

Esta pesquisa pôde constatar ainda que houve uma estreita relação entre a atividade creditícia e a economia de exportação, tendendo o mercado creditício a acompanhar os movimentos da economia de exportação, indicando a importância do crédito para a retomada da economia baiana de exportação, no final do período colonial.

A conjuntura externa favorável aos principais produtos baianos de exportação estimulou o alargamento do crédito, que, por sua vez, fomentou o crescimento da produção e da circulação, setores que, ao se expandirem, retroalimentaram o próprio setor creditício. Sendo uma economia de plantation escravista, viáveis economicamente apenas quando produzindo em larga escala, forcejou o setor exportador a se constituir como o principal carente do crédito.

Por fim, ressaltamos as características de uma categoria específica de crédito, o empréstimo de dinheiro a juros. Vinculada à economia de exportação e à conjuntura externa, a atividade prestamista não pareceu tão conectada ao crédito e, de um modo geral, oscilou bastante de um ano para outro: o empréstimo de dinheiro a juros na Bahia entre 1777 e 1808 teve tendências próprias. Não sendo o dinheiro uma mercadoria comum, seu percurso foi permeado por peculiaridades. Enquanto nas vendas a prazo, se vendia uma mercadoria qualquer, neste caso a mercadoria vendida era o próprio dinheiro. E esse, na referida sociedade, era algo muito valorizado, sendo que tal valorização não deve ser atribuída a um único elemento, seu alto valor não se resumiu a fatores econômicos, mas também a aspectos sociais e culturais.

Como dito, o dinheiro nessa sociedade esteve eventualmente indisponível, o que certamente possibilitou sua maior valorização econômica, não obstante, se faz necessário afirmar que o dinheiro, no período colonial, tem valor intrínseco, ou seja, além de dinheiro, era também metal precioso e, como tal, se constituiu dentro das teorias mercantilistas do período moderno, como um artigo que se manifestou, na prática, como algo que deveria ser entesourado. Seu alto valor, não apenas no que tange ao aspecto econômico, como também no aspecto sociocultural, não teve como

\footnotetext{
2 Arquivo Público do Estado da Bahia; Seção: Judiciário; Livros de Notas do $1^{\circ}$ e $2^{\circ}$ ofício de Salvador, anos de 1777 a 1808.
} 
consequência, a sua escassez, mas a sua indisponibilidade.

Optava-se na sociedade baiana colonial, por ofertar créditos em espécie, assim, o dinheiro se caracterizou, muitas vezes, como reserva de valor, utilizado em situações extraordinárias. Portanto, quando se tratou de crédito, o último recurso utilizado pelos "baianos" era o dinheiro, explicando porque o valor médio dos empréstimos foi tão inferior ao da atividade creditícia como um todo.

\section{Fontes}

Arquivo Público do Estado da Bahia- APEB. Seção: Judiciário; Livro de Notas nº 117 A. 02/01/1777 a 23/06/1777. Tabelião Manoel Antonio Campelo, 497 folhas.

Arquivo Público do Estado da Bahia- APEB. Seção: Judiciário; Livro de Notas n 118. 26/06/1777 a 30/10/1778. Tabelião Bernardino de Sena Araújo, 346 folhas.

Arquivo Público do Estado da Bahia- APEB. Seção: Judiciário; Livro de Notas n 119. 17/11/1777 a 16/08/1779. Tabelião Vicente José de Avilar, 372 folhas.

Arquivo Público do Estado da Bahia- APEB. Seção: Judiciário; Livro de notas n 120. 07/07/1778 a 02/01/1780. Tabelião Manoel Antonio Campelo, 497 folhas.

Arquivo Público do Estado da Bahia- APEB. Seção: Judiciário; Livro de notas 120 A. 12/02/1779 a 22/02/1780. Tabelião Bernardino de Sena Araújo, 274 folhas.

Arquivo Público do Estado da Bahia- APEB. Seção: Judiciário; Livro de Notas nº 122. 20/08/1779 a 26/12/1780. Tabelião Vicente José de Avilar, 406 folhas.

Arquivo Público do Estado da Bahia- APEB. Seção: Judiciário; Livro de notas nº 123. 14/01/1782 a 20/12/1783. Tabelião Bernardino de Sena Araújo, 390 folhas.

Arquivo Público do Estado da Bahia- APEB. Seção: Judiciário; Livro de Notas nº 124. 05/12/1783 a 07/01/1784. Tabelião Manoel Antonio Campelo, 389 folhas.

Arquivo Público do Estado da Bahia- APEB. Seção: Judiciário; Livro de notas no 125. 23/01/1784 a 05/11/1785. Tabelião Bernardino de Sena Araújo, 388 folhas.

Arquivo Público do Estado da Bahia- APEB. Seção: Judiciário; Livro de Notas n 126. 11/05/1785 a 15/12/1785. Tabelião Manoel Antonio Campelo, 235 folhas.

Arquivo Público do Estado da Bahia- APEB. Seção: Judiciário; Livro de Notas nº 126 A. 13/11/1785 a 26/12/1785. Tabelião João Damázio José, 119 folhas.

Arquivo Público do Estado da Bahia- APEB. Seção: Judiciário; Livro de Notas n 130. 07/04/1791 a 02/06/1792. Tabelião João Damásio José, 410 folhas.

Arquivo Público do Estado da Bahia- APEB. Seção: Judiciário; Livro de Notas nº 132. 20/03/1792 a 19/12/1793. Tabelião Bernardino de Sena Araújo, 450 folhas.

Arquivo Público do Estado da Bahia- APEB. Seção: Judiciário; Livro de Notas no 140. 08/09/1799 a 13/11/1800. Tabelião Joaquim José B. de Almeida, 496 folhas.

Arquivo Público do Estado da Bahia- APEB. Seção: Judiciário; Livro de Notas n 141. 10/09/1799 a 24/12/1800. Tabelião Joaquim Tavares de M. Silva, 492 folhas.

Arquivo Público do Estado da Bahia- APEB. Seção: Judiciário; Livro de Notas nº 143. 15/11/1800 a 23/05/1801. Tabelião Joaquim José B. de Almeida, 146 folhas. 
Arquivo Público do Estado da Bahia- APEB. Seção: Judiciário; Livro de Notas n 144. 27/11/1800 a 13/04/1802. Tabelião Joaquim Tavares de M. Silva, 516 folhas.

Arquivo Público do Estado da Bahia- APEB. Seção: Judiciário; Livro de Notas nº 145. 14/04/1802 a 25/01/1803. Tabelião Joaquim Tavares de M. Silva, 299 folhas.

Arquivo Público do Estado da Bahia- APEB. Seção: Judiciário; Livro de Notas no 146. 25/11/1803 a 12/01/1804. Tabelião Joaquim Tavares de M. Silva, 296 folhas.

Arquivo Público do Estado da Bahia- APEB. Seção: Judiciário; Livro de Notas n 147. 01/10/1801 a 19/11/1803. Tabelião Valetim Rodrigues Ferreira, 461 folhas.

Arquivo Público do Estado da Bahia- APEB. Seção: Judiciário; Livro de Notas nº 148. 19/11/1803 a 23/08/1804. Tabelião Joaquim Tavares de M. Silva, 298 folhas.

Arquivo Público do Estado da Bahia- APEB. Seção: Judiciário; Livro de Notas n 149. 27/07/1804 a 18/10/1804. Tabelião Luiz de V. da Silva Campelo, 100 folhas.

Arquivo Público do Estado da Bahia- APEB. Seção: Judiciário; Livro de Notas n 150. 20/11/1803 a 22/11/1804. Tabelião Valetim Rodrigues Ferreira, 213 folhas.

Arquivo Público do Estado da Bahia- APEB. Seção: Judiciário; Livro de Notas n 151. 28/08/1804 a 02/09/1805. Tabelião Manuel Ribeiro Carvalho, 220 folhas.

Arquivo Público do Estado da Bahia- APEB. Seção: Judiciário; Livro de Notas n 152. 06/11/1804 a 20/05/1805. Tabelião Jozé Álvares Quintas, 100 folhas.

Arquivo Público do Estado da Bahia- APEB. Seção: Judiciário; Livro de Notas n 153. 09/03/1805 a 02/11/1805. Tabelião Joaquim Tavares de M. Silva, 318 folhas.

Arquivo Público do Estado da Bahia- APEB. Seção: Judiciário; Livro de Notas n 154. 09/08/1805 a 09/10/1806. Tabelião Valetim Rodrigues Ferreira, 300 folhas.

Arquivo Público do Estado da Bahia- APEB. Seção: Judiciário; Livro de Notas nº 155. 05/11/1805 a 15/12/1805. Tabelião Joaquim Tavares de M. Silva, 349 folhas.

Arquivo Público do Estado da Bahia- APEB. Seção: Judiciário; Livro de Notas no 156. 16/12/1806 a 19/06/1807. Tabelião Joaquim Tavares de M. Silva, 156 folhas.

Arquivo Público do Estado da Bahia- APEB. Seção: Judiciário; Livro de Notas n 157. 25/06/1807 a 11/07/1808. Tabelião Joaquim Tavares de M. Silva, 356 folhas.

Arquivo Público do Estado da Bahia- APEB. Seção: Judiciário; Livro de Notas nº 158. 11/07/1807 a 10/09/1808. Tabelião Jozé Alvares Quintas, 224 folhas.

Arquivo Público do Estado da Bahia- APEB. Seção: Judiciário; Livro de Notas n 160. 27/03/1808 a 29/07/1809. Tabelião Francisco Alvares Albergaria, 301 folhas.

\section{Referências}

ARRUDA, José Jobson de Andrade. O Brasil no comércio colonial. São Paulo: Ática, 1980.

BARICKMAN, B. J. Um Contraponto baiano: açúcar, fumo, mandioca e escravidão no Recôncavo, 1789-1860. Rio de Janeiro. Ed. Civilização Brasileira, 2003.

BORGES, Eduardo Jose Santos. O Antigo Regime no Brasil colonial: elites e poder na Bahia do século XVIII. São Paulo: Alameda, 2015. 
FLORY, Rae Jean Dell. Bahia Society in the Mid. Colonial Period: The Sugar Planters, Tabacco Growers, Merchantes, and Artisans of Salvador and the Recôncavo, 1680-1725. PhD. University of Texas, 1978.

MASCARENHAS, Maria José Rapassi. Fortunas coloniais - Elite e riqueza em Salvador 1760 1808. São Paulo: Universidade de São Paulo, 1999. (Tese de Doutorado). 2018.

MATTOSO, Kátia. A Bahia do século XIX: Uma Província no Império. Rio de Janeiro: Nova Fronteira, 1972.

RAMINELLI, Ronald. Viagens Ultramarinas: monarcas, vassalos, e governo a distância. $1^{a}$ ed. São Paulo: Alameda, 2008.

SAMPAIO, Antonio Carlos Jucá de. Crédito e Circulação Monetária na Colônia: o caso Fluminense, 1650-1750. Anais do V Congresso Brasileiro de História Econômica, Caxambu: ABPHE, 2003.

SCHWARTZ, Stuart. Segredos Internos: Engenhos e Escravos na sociedade Colonial, 1550-1835. São Paulo: Companhia das Letras, 1988.

TAVARES, Luís Henrique Dias. História da Bahia. 10. ed. Salvador/São Paulo, Edufba/Ed. Unesp, 2001.

\section{Nota de autoria}

Augusto Fagundes da Silva dos Santos é doutor em História pela Universidade Federal da Bahia UFBA, mestre em História pela Universidade Federal da Bahia-UFBA e graduado em História pela Universidade Federal do Recôncavo da Bahia-UFRB. Atualmente é pós-doutorando em História pelo Programa de Pós-Graduação em História da Universidade Federal Fluminense-UFF, integrando a linha de Pesquisa Economia e Sociedade e Professor de História Econômica da Universidade Estadual de Feira de Santana-UEFS. E-mail: augustofagundes@uefs.br.

\section{Como citar esse artigo de acordo com as normas da revista}

SANTOS, Augusto Fagundes da Silva dos. O mercado creditício na Bahia colonial (1777-1808). Sæculum - Revista de História, v. 26, n. 44, p. 251-265, 2021.

\section{Contribuição de autoria}

Não se aplica.

\section{Financiamento}

Não se aplica.

\section{Consentimento de uso de imagem}

Não se aplica.

\section{Aprovação de comitê de ética em pesquisa}

Não se aplica.

\section{Licença de uso}

Este artigo está licenciado sob a Licença Creative Commons CC-BY. Com essa licença você pode compartilhar, adaptar, criar para qualquer fim, desde que atribua a autoria da obra.

\section{Histórico}

Recebido em 27/01/2021.

Modificações solicitadas em 09/04/2021.

Aprovado em 12/05/2020. 